\title{
Quantifying TOLNet ozone lidar accuracy during the 2014 DISCOVER-AQ and FRAPPÉ campaigns
}

\author{
Lihua Wang ${ }^{1}$, Michael J. Newchurch ${ }^{1}$, Raul J. Alvarez II $^{2}$, Timothy A. Berkoff ${ }^{3}$, Steven S. Brown ${ }^{2}$, \\ William Carrion $^{3,4}$, Russell J. De Young ${ }^{3}$, Bryan J. Johnson ${ }^{2}$, Rene Ganoe ${ }^{4}$, Guillaume Gronoff ${ }^{3,4}$, \\ Guillaume Kirgis $^{2,5}$, Shi Kuang ${ }^{1}$, Andrew O. Langford ${ }^{2}$, Thierry Leblanc ${ }^{6}$, Erin E. McDuffie ${ }^{2,5,7}$, Thomas J. McGee ${ }^{8}$, \\ Denis Pliutau ${ }^{4}$, Christoph J. Senff ${ }^{2,5}$, John T. Sullivan ${ }^{8,9}$, Grant Sumnicht ${ }^{4}$, Laurence W. Twigg ${ }^{4}$, and \\ Andrew J. Weinheimer ${ }^{10}$ \\ ${ }^{1}$ University of Alabama in Huntsville, Huntsville, Alabama, USA \\ ${ }^{2}$ NOAA Earth System Research Laboratory, Boulder, Colorado, USA \\ ${ }^{3}$ NASA Langley Research Center, Hampton, Virginia, USA \\ ${ }^{4}$ Science Systems and Applications Inc., Lanham, Maryland, USA \\ ${ }^{5}$ Cooperative Institute for Research in Environmental Sciences, University of Colorado, Boulder, Colorado, USA \\ ${ }^{6}$ Jet Propulsion Laboratory, California Institute of Technology, Wrightwood, California, USA \\ ${ }^{7}$ Department of Chemistry, University of Colorado, Boulder, Colorado, USA \\ ${ }^{8}$ NASA Goddard Space Flight Center, Greenbelt, Maryland, USA \\ ${ }^{9}$ Joint Center for Earth Systems Technology, Baltimore, Maryland, USA \\ ${ }^{10}$ National Center for Atmospheric Research, Boulder, Colorado, USA
}

Correspondence to: Shi Kuang (kuang@nsstc.uah.edu)

Received: 7 April 2017 - Discussion started: 22 May 2017

Revised: 25 August 2017 - Accepted: 13 September 2017 - Published: 23 October 2017

\begin{abstract}
The Tropospheric Ozone Lidar Network (TOL$\mathrm{Net}$ ) is a unique network of lidar systems that measure highresolution atmospheric profiles of ozone. The accurate characterization of these lidars is necessary to determine the uniformity of the network calibration. From July to August 2014, three lidars, the TROPospheric OZone (TROPOZ) lidar, the Tunable Optical Profiler for Aerosol and oZone (TOPAZ) lidar, and the Langley Mobile Ozone Lidar (LMOL), of TOLNet participated in the Deriving Information on Surface conditions from Column and Vertically Resolved Observations Relevant to Air Quality (DISCOVERAQ) mission and the Front Range Air Pollution and Photochemistry Éxperiment (FRAPPÉ) to measure ozone variations from the boundary layer to the top of the troposphere. This study presents the analysis of the intercomparison between the TROPOZ, TOPAZ, and LMOL lidars, along with comparisons between the lidars and other in situ ozone instruments including ozonesondes and a P-3B airborne chemiluminescence sensor. The TOLNet lidars measured vertical ozone structures with an accuracy generally better than $\pm 15 \%$ within the troposphere. Larger differences occur at
\end{abstract}

some individual altitudes in both the near-field and far-field range of the lidar systems, largely as expected. In terms of column average, the TOLNet lidars measured ozone with an accuracy better than $\pm 5 \%$ for both the intercomparison between the lidars and between the lidars and other instruments. These results indicate that these three TOLNet lidars are suitable for use in air quality, satellite validation, and ozone modeling efforts.

\section{Introduction}

\subsection{TOLNet}

The Tropospheric Ozone Lidar Network (TOLNet) provides time-height measurements of ozone from the planetary boundary layer (PBL) to the top of the troposphere at multiple locations for satellite validation, model evaluation, and scientific research (Newchurch et al., 2016; http://www-air. larc.nasa.gov/missions/TOLNet/). Particularly, these ozone measurements can serve to validate NASA's first Earth Ven- 
ture Instrument mission, Tropospheric Emissions: Monitoring Pollution (TEMPO), planned to launch in 2019. A second objective of TOLNet is to identify a brassboard ozone lidar instrument that would be suitable to populate a network to address an increasing need for ozone profiles by scientists and managers within the air quality, modeling, and satellite communities (Bowman, 2013).

TOLNet consists of five ozone lidars across the United States and one in Canada: the Table Mountain tropospheric ozone differential absorption lidar (DIAL) at NASA's Jet Propulsion Laboratory, the Tunable Optical Profiler for Aerosol and oZone (TOPAZ) lidar at NOAA's Earth System Research Laboratory (ESRL), the Rocket-city Ozone $\left(\mathrm{O}_{3}\right)$ Quality Evaluation in the Troposphere $\left(\mathrm{RO}_{3} \mathrm{QET}\right)$ lidar at the University of Alabama in Huntsville (UAH), the TROPospheric OZone (TROPOZ) DIAL at NASA's Goddard Space Flight Space Center (GSFC), the Langley Mobile Ozone Lidar (LMOL) at NASA's Langley Research Center (LaRC), and the Autonomous Mobile Ozone Lidar Instrument for Tropospheric Experiments (AMOLITE) at Environment and Climate Change Canada.

All TOLNet lidars have unique configurations of original measurement design purposes, including their transmitter, receiver, and signal processing systems. Most components of these lidars are customized and differ significantly in pulse energy, repetition rate, receiver size, solar (or narrow-band) interference filter, and range resolution. These differences result in varying signal-to-noise ratios (SNRs), which impact the useful operating ranges and statistical uncertainties in ozone retrieval. The selection of the DIAL wavelengths determines the sensitivity to interference by other species, primarily aerosols. In addition, multiple lidar data processing and retrieval algorithms could also lead to different effective resolutions and lidar retrieval uncertainties (Godin et al., 1999; Leblanc et al., 2016a, b). Therefore, it is important to quantify the measurement differences between the TOLNet lidars and understand their sources before we can form a consistent TOLNet dataset. A previous intercomparison between TROPOZ and LMOL reported by Sullivan et al. (2015) concluded that the observed ozone column averages from the two lidars were within $\pm 8 \%$ of each other, and their ozone profiles were mostly within $\pm 10 \%$ of each other.

\subsection{DISCOVER-AQ 2014 and FRAPPÉ campaigns}

The scientific goal of the TOLNet lidars in this study was to provide continuous, high-resolution tropospheric ozone profiles to support the NASA-sponsored DISCOVER-AQ mission (https://www.nasa.gov/larc/ 2014-discoveraq-campaign/), and the National Science Foundation (NSF) and state of Colorado (CO) jointly sponsored FRAPPÉ (Dingle et al., 2016) from July to August 2014. By collaborating with FRAPPÉ, the 2014 CO study was the final stop in a series of four field campaigns by DISCOVER-AQ to understand sources, transport, and chemical transformations of air pollutants, particularly those that lead to ground-level ozone formation (Crawford and Pickering, 2014).

Prior to the two campaigns, TOPAZ, TROPOZ, and LMOL were all deployed to the same location in Erie, $\mathrm{CO}$, to obtain intercomparison data at the Boulder Atmospheric Observatory (BAO) $\left(40.050^{\circ} \mathrm{N}, 105.003^{\circ} \mathrm{W} ; 1584 \mathrm{~m}\right.$ above sea level, a.s.l.). Subsequent to the BAO intercomparison, TROPOZ and LMOL re-deployed to locations near Fort Collins, $\mathrm{CO}(\sim 60 \mathrm{~km}$ north-northwest of BAO), and Golden, $\mathrm{CO}(\sim 40 \mathrm{~km}$ southwest of BAO), respectively, for their different scientific missions. During the DISCOVERAQ and FRAPPÉ campaigns, balloon-borne ozonesondes were launched at selected sites. In addition, the NASA P3B aircraft performed multiple spiral ascents and descents over several ground sites and provided measurements of ozone profiles. In this study, we compare retrievals between the three lidars and evaluate the ozone lidar accuracy using ozonesonde and P-3B aircraft measurements. These two campaigns offered a unique opportunity for the lidar validation work, as they involved so many different instruments.

\section{Instruments}

\subsection{TOLNet lidars}

Table 1 lists the main hardware specifications of the three TOLNet lidars and their ozone retrieval processes, which could potentially impact the intercomparison result.

\subsubsection{TROPOZ/NASA GSFC}

The transmitter for TROPOZ consists of two $50 \mathrm{~Hz} \mathrm{Nd:YAG}$ lasers used to pump two Raman cells filled with deuterium $\left(\mathrm{D}_{2}\right)$ and hydrogen $\left(\mathrm{H}_{2}\right)$ gases to generate two outgoing pulses at $289 \mathrm{~nm}$ (online) and $299 \mathrm{~nm}$ (offline). The typical pulse energies are $12 \mathrm{~mJ}$ at $299 \mathrm{~nm}$ and $16 \mathrm{~mJ}$ at $289 \mathrm{~nm}$ (Sullivan et al., 2014). The receiving system consists of a $45 \mathrm{~cm}$ diameter Newtonian telescope for measuring far field and four smaller $2.5 \mathrm{~cm}$ refracting telescopes to measure near field. The $45 \mathrm{~cm}$ telescope has a $1 \mathrm{mrad}$ field of view (FOV), and the $2.5 \mathrm{~cm}$ telescopes have a much wider FOV at $10 \mathrm{mrad}$. In each channel, solar interference filters with a $1 \mathrm{~nm}$ bandwidth decrease the amount of ambient solar light, which improves the SNR. The fundamental range resolution for the data acquisition system is $15 \mathrm{~m}$ ( $100 \mathrm{~ns})$. TROPOZ measures ozone up to $16 \mathrm{~km}$ during daytime hours and higher altitudes at night.

\subsubsection{TOPAZ/NOAA ESRL}

The TOPAZ lidar is a truck-mounted scanning instrument modified from the nadir-looking airborne DIAL configuration first used in the 2006 Texas Air Quality Study (Tex- 
Table 1. Specifications for the TOLNet lidars.

\begin{tabular}{|c|c|c|c|}
\hline & TROPOZ & TOPAZ & LMOL \\
\hline \multicolumn{4}{|c|}{ Transmitter } \\
\hline Laser type & $\begin{array}{l}\mathrm{Nd} \text { :YAG pumped } \mathrm{D}_{2} \\
\mathrm{H}_{2} \text { Raman cell }\end{array}$ & $\begin{array}{l}\text { Nd:YLF pumped } \\
\text { Ce:LiCAF }\end{array}$ & $\begin{array}{l}\text { Nd:YLF pumped } \\
\text { Ce:LiCAF }\end{array}$ \\
\hline Wavelengths (nm) & $288.9,299.1$ & $287,291,294$ & $287.1,292.7$ \\
\hline $\begin{array}{l}\text { Pulse repetition } \\
\text { rate }(\mathrm{Hz})\end{array}$ & 50 & 333 & 500 \\
\hline Pulse energy (mJ) & $\begin{array}{l}12(299 \mathrm{~nm}) \\
16(289 \mathrm{~nm})\end{array}$ & $\begin{array}{l}\sim 0.06 \text { for } \\
\text { all wavelengths }\end{array}$ & $\begin{array}{l}0.2 \text { for both } \\
\text { wavelengths }\end{array}$ \\
\hline \multicolumn{4}{|c|}{ Detection and data acquisition system } \\
\hline Telescope diameter $(\mathrm{cm})$ & $45,2.5$ & 50 & 40,30 \\
\hline FOV (mrad) & $\begin{array}{l}1(45 \mathrm{~cm}) \\
10(2.5 \mathrm{~cm})\end{array}$ & $\begin{array}{l}1.5 \text { (far-field channel), } \\
3 \text { (near-field channel) }\end{array}$ & $\begin{array}{l}1.4 \text { (far-field channel), } \\
\text { variable FOV (near-field channel) }\end{array}$ \\
\hline Signal detection type & PMT & PMT & PMT \\
\hline Data acquisition type & $\mathrm{PC}$ & analog & analog and PC \\
\hline $\begin{array}{l}\text { Fundamental range } \\
\text { resolution }(\mathrm{m})\end{array}$ & 15 & 6 & 7.5 \\
\hline Instrument reference & Sullivan et al. (2014) & Alvarez et al. (2011) & DeYoung et al. (2017) \\
\hline \multicolumn{4}{|c|}{ DIAL retrieval } \\
\hline $\begin{array}{l}\text { DIAL retrieval } \\
\text { and smoothing } \\
\text { method }\end{array}$ & $\begin{array}{l}\text { first-order (differential) SG filter } \\
\text { with a second-degree polynomial } \\
\text { with an increasing window width } \\
\text { applied on the derivative of } \\
\text { the logarithm of the signal ratios }\end{array}$ & $\begin{array}{l}\text { five-point least-squares fit } \\
\text { with a } 450 \mathrm{~m} \text { window } \\
\text { applied on the derivative } \\
\text { of the logarithm } \\
\text { of the signal ratios }\end{array}$ & $\begin{array}{l}\text { first-order (differential) SG filter } \\
\text { with a second-degree polynomial, } \\
\text { with an increasing window width } \\
\text { applied the derivative of the } \\
\text { logarithm of the signal ratios }\end{array}$ \\
\hline $\begin{array}{l}\text { Retrieval effective } \\
\text { resolution }(\mathrm{m})\end{array}$ & $\begin{array}{l}\sim 100 \text { at } 1 \mathrm{~km} \text { degrading } \\
\text { to } \sim 800 \text { at } 10 \mathrm{~km}\end{array}$ & $\begin{array}{l}\sim 10 \text { below } 50 \mathrm{~m}, \\
\sim 30 \text { from } 50 \text { to } 150 \mathrm{~m}, \\
\sim 100 \text { from } 150 \text { to } 500 \mathrm{~m}, \\
315 \text { above } 500 \mathrm{~m}\end{array}$ & $\begin{array}{l}225 \text { below } 3 \mathrm{~km} \text { degrading } \\
\text { to } 506 \text { above } 3 \mathrm{~km}\end{array}$ \\
\hline $\begin{array}{l}\text { Aerosol correction } \\
\text { reference }\end{array}$ & $\begin{array}{l}\text { Kuang et al. (2011), } \\
\text { Sullivan et al. (2014) }\end{array}$ & Alvarez et al. (2011) & $\begin{array}{l}\text { Browell et al. (1985), } \\
\text { DeYoung et al. (2017) }\end{array}$ \\
\hline $\begin{array}{l}\text { Valid altitudes (km above } \\
\text { ground level, a.g.l.) }\end{array}$ & $0.35-16$ & $0.01-2$ & $0.7-4.5$ \\
\hline
\end{tabular}

\begin{tabular}{llll}
\hline & & Measurement location \\
\hline Latitude $\left({ }^{\circ} \mathrm{N}\right)$ & 40.050 & 40.045 & 40.050 \\
\hline Longitude $\left({ }^{\circ} \mathrm{W}\right)$ & 105.000 & 105.006 & 105.004 \\
\hline Elevation $(\mathrm{m}$ a.s.l. $)$ & 1584 & 1587 & 1584 \\
\hline
\end{tabular}

AQS II) (Alvarez et al., 2011; Senff et al., 2010). The lidar transmitter is based on a Ce:LiCAF laser pumped by a quadrupled Nd:YLF laser to produce three UV wavelengths, each at a $333 \mathrm{~Hz}$ repetition rate and tunable from 283 to $310 \mathrm{~nm}$. The actual wavelengths used during DISCOVERAQ 2014 were 287, 291, and $294 \mathrm{~nm}$. Compared to the conventional two-wavelength DIAL, the three-wavelength con- figuration can potentially minimize the aerosol interference by using the dual-DIAL retrieval technique (Kovalev and Bristow, 1996) without assuming a lidar ratio and Ångström exponent. However, in this study, ozone was retrieved using the 287 and $294 \mathrm{~nm}$ lidar signals and the standard twowavelength DIAL algorithm because the two-wavelength re- 
trieval was less affected by significant lidar signal noise (Alvarez et al., 2011).

Laser light backscattered by air molecules and aerosol particles is collected with a co-axial $50 \mathrm{~cm}$ diameter Newtonian telescope and then split at a 1:9 ratio into near- and farfield detection channels. The FOVs of the near- and far-field channels are controlled by different-sized apertures resulting in full overlap at distances of $\sim 300$ and $\sim 800 \mathrm{~m}$, respectively. Both channels use gated photomultipliers (PMTs) operated in analog mode with solar interference filters during the daytime. Compared to photon counting (PC) signals, the analog signal is able to maintain high linearity for strong signals and is particularly suitable for near-range measurements. The two-axis scanner on the truck sequentially points the laser beam at 2, 6, 20, and $90^{\circ}$ elevation angles in a cycle taking approximately $5 \mathrm{~min}$. The azimuth angle was fixed throughout the experiment. The ozone profiles at these four angles are spliced together to create composite vertical profiles extending from $10 \mathrm{~m}$ to about $2 \mathrm{~km}$ a.g.l. (Langford et al., 2016). The range resolution of the signal recording system is $6 \mathrm{~m}$.

During the 2014 DISCOVER-AQ and FRAPPÉ campaigns, the TOPAZ ozone observations suffered from a slight but consistent range-dependent bias created by an unknown source of noise in the data acquisition system. The cause of this noise remains unknown and attempts to correct the resulting bias were unsuccessful. This bias manifests itself primarily in the low-elevation-angle observations $\left(2,6\right.$, and $\left.20^{\circ}\right)$ because the signal levels and SNRs are significantly lower compared to the measurements at $90^{\circ}$. For these reasons, the low angle observations below $500 \mathrm{~m}$ were excluded from the comparisons reported within this study.

\subsubsection{LMOL/NASA LaRC}

The transmitter of LMOL consists of a diode-pumped Nd:YLF laser pumping a Ce:LiCAF tunable UV laser to obtain two wavelengths typically at 287.1 and $292.7 \mathrm{~nm}$ with a pulse energy of $0.2 \mathrm{~mJ}$ at $500 \mathrm{~Hz}$ for each wavelength. The lidar receiver system consists of a $40 \mathrm{~cm}$ telescope with a $1.4 \mathrm{mrad}$ FOV to measure far field and another $30 \mathrm{~cm}$ telescope with an adjustable FOV to measure near field (De Young et al., 2017). The raw lidar signals are recorded with a $7.5 \mathrm{~m}$ range resolution. The LMOL data acquisition system operates in both analog and PC modes. In this study, LMOL measures ozone between 0.7 and $4.5 \mathrm{~km}$. Ozone measurements for DISCOVER-AQ represent LMOL's very first remote deployment.

\subsubsection{Lidar data processing and retrieval algorithms}

The data processing and DIAL retrieval algorithms for the three TOLNet lidars are similar but not identical. Their details have been described by Alvarez et al. (2011), De Young et al. (2017), Langford et al. (2011), and Sullivan et al. (2015,
2014). Some basic procedures were applied on the raw lidar signals before retrievals, such as time integration ( $5 \mathrm{~min}$ for this study), dead-time correction (for PC only), background correction (subtraction), merging of PC and analog signals (for a system with both PC and analog channels), and signalinduced-bias (SIB) correction (Kuang et al., 2013). Some parameters are system dependent or empirical due to different equipment, such as the dead-time value, $\mathrm{PC}$-analog timing offset, averaging range for background calculation, and SIB function form. All groups agreed to use the Brion-DaumontMalicet (Daumont et al., 1992; Malicet et al., 1995; Brion et al., 1993) ozone absorption cross sections, which are temperature dependent.

The ozone number density profile results from computing the derivative of the logarithm of the online to offline signal ratios. Spatial (range) smoothing is usually necessary to improve the SNR and reduce the statistical errors. Various smoothing methods and their impacts on final lidar retrieval have been described by Godin et al. (1999). Both TROPOZ and LMOL groups applied a Savitzky-Golay (SG) filter with a second-degree polynomial on the derivative of the logarithm of the online to offline signal ratios with an increasing window width to accommodate the quickly decreasing SNR. However, the SG window sizes for TROPOZ and LMOL are different due to different SNRs at each altitude. The TOPAZ group averaged lidar signal over $90 \mathrm{~m}$ and, then, smoothed the derivative of the logarithm of the signal ratios with a five-point least-squares fit in a $450 \mathrm{~m}$ window. The different retrieval methodologies and parameters affect the effective vertical resolution of the retrieved ozone profiles (Leblanc et al., 2016a), as listed in Table 1. This effective resolution determines the capability of the lidars to resolve vertical ozone structure and is not equal to, but is associated with, the fitting window width.

All groups applied similar schemes to correct the aerosol interference. These schemes iteratively substitute derived ozone from the DIAL equation into the lidar equation to solve aerosol extinction and backscatter until both aerosol and ozone converge (Alvarez et al., 2011; Kuang et al., 2011; Sullivan et al., 2014). The differential aerosol backscatter and extinction were calculated with the approximation from Browell et al. (1985). Lidars directly measure the ozone number density, and all three groups used the same temperature and pressure profiles from co-located ozonesonde measurements for Rayleigh correction, ozone mixing-ratio calculations, and computation of the temperature-dependent ozone absorption cross sections.

Merging between different altitude channels, either different telescopes or different optical channels of the same telescope, is challenging with limited methodologies reported in the literature (Kuang et al., 2011). It is difficult to specify a method for all groups because merging is system-dependent and is affected by many factors previously described. Therefore, the three lidar groups merge the ozone profiles at different altitudes optimized for their system and SNR levels such 
Table 2. Maximum $1 \sigma$ uncertainties for TROPOZ, TOPAZ, and LMOL daytime ozone measurements within their measurable range for the 5 and 30 min integration time.

\begin{tabular}{|c|c|c|c|c|c|c|}
\hline \multirow{3}{*}{$\begin{array}{l}\text { Source } \\
\text { Lidar }\end{array}$} & \multicolumn{6}{|c|}{ Maximum uncertainty within each lidar's measurement range } \\
\hline & \multicolumn{3}{|c|}{5 min integration } & \multicolumn{3}{|c|}{30 min integration } \\
\hline & TROPOZ & TOPAZ & LMOL & TROPOZ & TOPAZ & LMOL \\
\hline Measurement range $(\mathrm{km})$ & $0.35-16$ & $0.01-2$ & $0.7-4.5$ & $0.35-16$ & $0.01-2$ & $0.7-4.5$ \\
\hline Statistical uncertainty ${ }^{\mathrm{a}}$ & $20 \%$ & $8 \%$ & $15 \%$ & $8 \%$ & $3 \%$ & $6 \%$ \\
\hline Background correction $^{\mathrm{a}}$ & $10 \%$ & $3 \%$ & $5 \%$ & $10 \%$ & $3 \%$ & $5 \%$ \\
\hline Saturation correction $^{b}$ & $1 \%$ & $\mathrm{n} / \mathrm{a}$ & $5 \%$ & $1 \%$ & $\mathrm{n} / \mathrm{a}$ & $5 \%$ \\
\hline Aerosol interference & $10 \%$ & $10 \%$ & $10 \%$ & $10 \%$ & $10 \%$ & $10 \%$ \\
\hline Interference by $\mathrm{SO}_{2}, \mathrm{NO}_{2}, \mathrm{O}_{2}$ dimer & $3 \%$ & $1 \%$ & $1 \%$ & $3 \%$ & $1 \%$ & $1 \%$ \\
\hline Differential Rayleigh scattering & $3 \%$ & $3 \%$ & $3 \%$ & $3 \%$ & $3 \%$ & $3 \%$ \\
\hline Ozone absorption cross section & $3 \%$ & $3 \%$ & $3 \%$ & $3 \%$ & $3 \%$ & $3 \%$ \\
\hline Total uncertainty ${ }^{\mathrm{c}}$ & $25 \%$ & $14 \%$ & $19 \%$ & $20 \%$ & $12 \%$ & $13 \%$ \\
\hline
\end{tabular}

${ }^{\text {a }}$ Range dependent and increasing with altitude.

b Range dependent and typically maximized at the near range.

c Total root-mean-square uncertainty by considering the range dependent uncertainties (also see Figs. 3 and 4).

as the example method described by Sullivan et al. (2015). As a result, additional differences between systems can occur due to the altitude channel merging.

\subsubsection{Error budget of the lidar measurements}

Only a brief description of the error budget of the lidar measurements is provided in this paper since the details have been discussed in the respective instrument papers (Alvarez et al., 2011; De Young et al., 2017; Sullivan et al., 2014). Table 2 presents the estimated daytime measurement uncertainties for 5 and $30 \mathrm{~min}$ integration time for the three lidars. Statistical uncertainties (Papayannis et al., 1990) arising from signal fluctuations are random errors and may be improved by additional averaging or smoothing. The statistical uncertainty, often referred to as measurement precision, generally increases with range due to decreasing SNR and is different for the three lidars due to their different laser power, telescope sizes, and measurement ranges. The uncertainty associated with background correction also increases with range because of decreasing signal levels. The uncertainty due to the saturation correction of the PC signals (Donovan et al., 1993) is also range dependent and typically maximizes at near range. The uncertainty arising from aerosol interference could be the largest systematic error source and can be minimized by using the appropriate correction algorithm (Eisele and Trickl, 2005; Immler, 2003; Sullivan et al., 2014). The absorption by sulfur dioxide $\left(\mathrm{SO}_{2}\right)$ varies significantly with wavelength in the Hartley band. For the TOPAZ and LMOL systems, the differential $\mathrm{SO}_{2}$ absorption cross section (Rufus et al., 2003) is only about one-eighth of their differential ozone absorption cross section so that the $\mathrm{SO}_{2}$ interference is negligible unless very high ambient $\mathrm{SO}_{2}$ concentrations are present. For TROPOZ with the 289-299 nm pair, the differential absorption cross section of $\mathrm{SO}_{2}$ is about half of the ozone differential absorption cross section, resulting in $1 \mathrm{ppb} \mathrm{SO}_{2}$ being registered as $0.5 \mathrm{ppb}$ ozone. Under typical atmospheric condition when $\mathrm{SO}_{2}$ concentrations are less than $2 \mathrm{ppb}$ (Heikes et al., 1987) and ozone concentrations are about $60 \mathrm{ppb}$, the $\mathrm{SO}_{2}$-induced error is less than $2 \%$ (Sullivan et al., 2014). However, $\mathrm{SO}_{2}$ can cause a more significant ozone bias when high $\mathrm{SO}_{2}$ concentrations are present such as in power plant or volcanic plumes. The estimated total lidar measurement uncertainties (Leblanc et al., 2016b) for a 30 min signal integration time are less than 20,12 , and $13 \%$ for TROPOZ, TOPAZ, and LMOL, respectively, within the lidar measurement ranges listed in Table 1.

\subsection{Ozonesondes}

An ozonesonde is a lightweight, balloon-borne instrument that consists of an air pump and an ozone sensor interfaced to a meteorological radiosonde. Ozonesondes are capable of measuring ozone under various weather conditions (e.g., cloudy, thunderstorm). The ozone sensor uses an electrochemical concentration cell (ECC) containing potassium iodide (KI) solution (Komhyr, 1969; Komhyr et al., 1995) to measure ozone with a precision better than $\pm 5 \%$ and an accuracy better than $\pm 10 \%$ up to $35 \mathrm{~km}$ altitude with a sampling interval of about $1 \mathrm{~s}$ and a retrieval vertical resolution of $100 \mathrm{~m}$ (Deshler et al., 2008; Johnson et al., 2008; Smit et al., 2007). A radiosonde attached in the same package measures air temperature, pressure, and relative humidity (Stauffer et al., 2014). The uncertainty of ozonesonde measurements is typically larger in the troposphere than that in the stratosphere (Liu et al., 2009). It has been reported that the ECC sondes suffer interference from $\mathrm{SO}_{2}$ (Flentje et al., 2010) with $1 \mathrm{ppb} \mathrm{SO}_{2}$ being registered as $-1 \mathrm{ppb}$ ozone (Schenkel and Broder, 1982). Elevated $\mathrm{SO}_{2}$ can be a concern for lidar-ozonesonde intercomparison for some li- 
dar wavelengths (e.g., 289-299 nm) because of the opposite signs of the measurement error arising from $\mathrm{SO}_{2}$ for lidar and ozonesondes. However, this is not an issue for this study since we did not find any noticeable interference from $\mathrm{SO}_{2}$ in either lidar or ozonesonde data.

\subsection{Ozone measurement instrument on board NASA's P-3B}

NASA's P-3B aircraft is a pressurized, four-engine turboprop, capable of long-duration flights of $8-12 \mathrm{~h}$ and is based out of NASA's Wallops Flight Facility in Wallops Island, Virginia. A series of gas and aerosol instruments was outfitted within the P-3B aircraft. Ozone was measured using the National Center for Atmospheric Research (NCAR)'s fourchannel chemiluminescence instrument based on the reaction between ambient ozone and nitric oxide (NO) with an accuracy of about $\pm 5 \%$ and sampling interval of $1 \mathrm{~s}$ (Weinheimer et al., 1993; Ridley et al., 1992). The precision of this ozone detector is better than $\pm 1 \%$ when ambient ozone is higher than $10 \mathrm{ppbv}$. The P-3B aircraft flew spirals from 300 to $4570 \mathrm{~m}$ above the surface over selected ground monitoring sites including all three lidar sites (more information in Sect. 3) during the DISCOVER-AQ 2014 campaign.

\section{Results}

\subsection{Lidar intercomparisons}

The three TOLNet lidars were deployed next to the BAO tower to take simultaneous measurements before the DISCOVER-AQ/FRAPPÉ campaign. They were only a few hundreds of meters away from each other and were within $5 \mathrm{~m}$ of the same elevation (see measurement locations in Table 1).

Unlike stratospheric ozone lidars that focus on integrating hours of observations (Steinbrecht et al., 2009; McDermid et al., 1990), tropospheric ozone lidars need to detect ozone variations with timescales on the order of minutes, when considering ozone's shorter lifetime, smallerscale transport, and mixing processes within the PBL and free troposphere. Therefore, we processed all lidar data on a 5 min temporal scale (signal integration time). Rayleigh correction was performed with the same atmospheric profile from the ozonesonde. Because the three lidars have different fundamental range resolutions, retrieved ozone number density values were internally interpolated on the same altitude grid with a $15 \mathrm{~m}$ interval for comparison.

Figure 1 presents the comparison of the TOPAZ and TROPOZ observed ozone at BAO from 13:00 to 21:35 UTC (local, mountain daylight time is UTC-6) on 11 July 2014 under a partly cloudy sky condition. Data influenced by clouds were filtered out. Ozone time-height curtains from both lidars (Fig. 1a and b) show a significant (about 40\%) ozone increase in the early afternoon. A total of 7655 TOPAZ and TROPOZ coincident pairs were constructed between 0.6 and $2 \mathrm{~km}$ a.g.l. (altitude range over which both lidars provided valid data) over this time period. The measurement differences between the two lidars are mostly within $\pm 5 \%$ at individual grids (Fig. 1c). The value of averaged ozone concentration over some specified altitude range can represent the atmospheric ozone abundance and can be useful for satellite validation. Here, we refer to this value as ozone column average with the unit of number density, not to be confused with integrated column ozone often reported in Dobson units. The statistics of the intercomparison of the column averages is listed in Table 3 . The similar $1 \sigma$ standard deviations $\left(17.8\right.$ and $16.7 \times 10^{16}$ molec m$^{-3}$ ) suggest similar ozone variations captured by both lidars (also see Fig. 1a and b). The mean relative difference (or normalized bias) was calculated by averaging the relative difference (i.e., (TROPOZ-TOPAZ)/TOPAZ; the denominator was arbitrarily chosen) for all paired ozone profiles. The $-1.1 \pm 2.6 \%$ mean relative difference suggests excellent agreement of the averaged ozone column (Fig. 1d) for 80 profiles over $6.5 \mathrm{~h}$ between TOPAZ and TROPOZ retrievals.

Figure 2 shows the TOPAZ-LMOL intercomparison for data taken on 16 July 2014 with 1902 coincident pairs from 0.9 to $2 \mathrm{~km}$ and between 13:40 and 17:30 UTC on this day. Some of the data gaps were due to low clouds blocking the lidar beams. The retrievals between the two lidars agree with each other mostly within $\pm 10 \%$ (Fig. 2c). LMOL measured a mean ozone column average (Fig. 2d) $3.8 \pm 2.9 \%$ lower than TOPAZ for a total of 28 paired profiles, which is significantly fewer than those from the TROPOZ-TOPAZ comparison. This small but statistically significant ozone column difference could be due to errors in the background and saturation corrections or biases introduced by the merging of signals or ozone retrievals from different instrument channels. Almost the same $1 \sigma$ of ozone column average in Table 3 suggests that the two lidars measured similar temporal ozone variations. The $1 \sigma$ bars on the column average in Fig. $2 \mathrm{~d}$ represent the vertical ozone variability captured by lidar at a certain time. It can be seen that the two lidars measured highly similar vertical variability as well. The consistency in capture of ozone variability for TOPAZ and LMOL is in part due to their similar statistical uncertainties and vertical resolutions. The generally random distribution of the relative differences in Figs. 1c and 2c suggests overall consistent measurements with small systematic errors from all three lidars. In summary, TROPOZ, LMOL, and TOPAZ report ozone values at individual altitudes mostly within $\pm 10 \%$, which is well within their respective uncertainties and report ozone column averages within $\pm 3.8 \%$ on average.

\subsection{Lidars versus ozonesondes}

In order to compare the lidar data to ozonesondes, the Rayleigh- and aerosol-corrected lidar data were converted from ozone number densities to ozone mixing ratios by using 

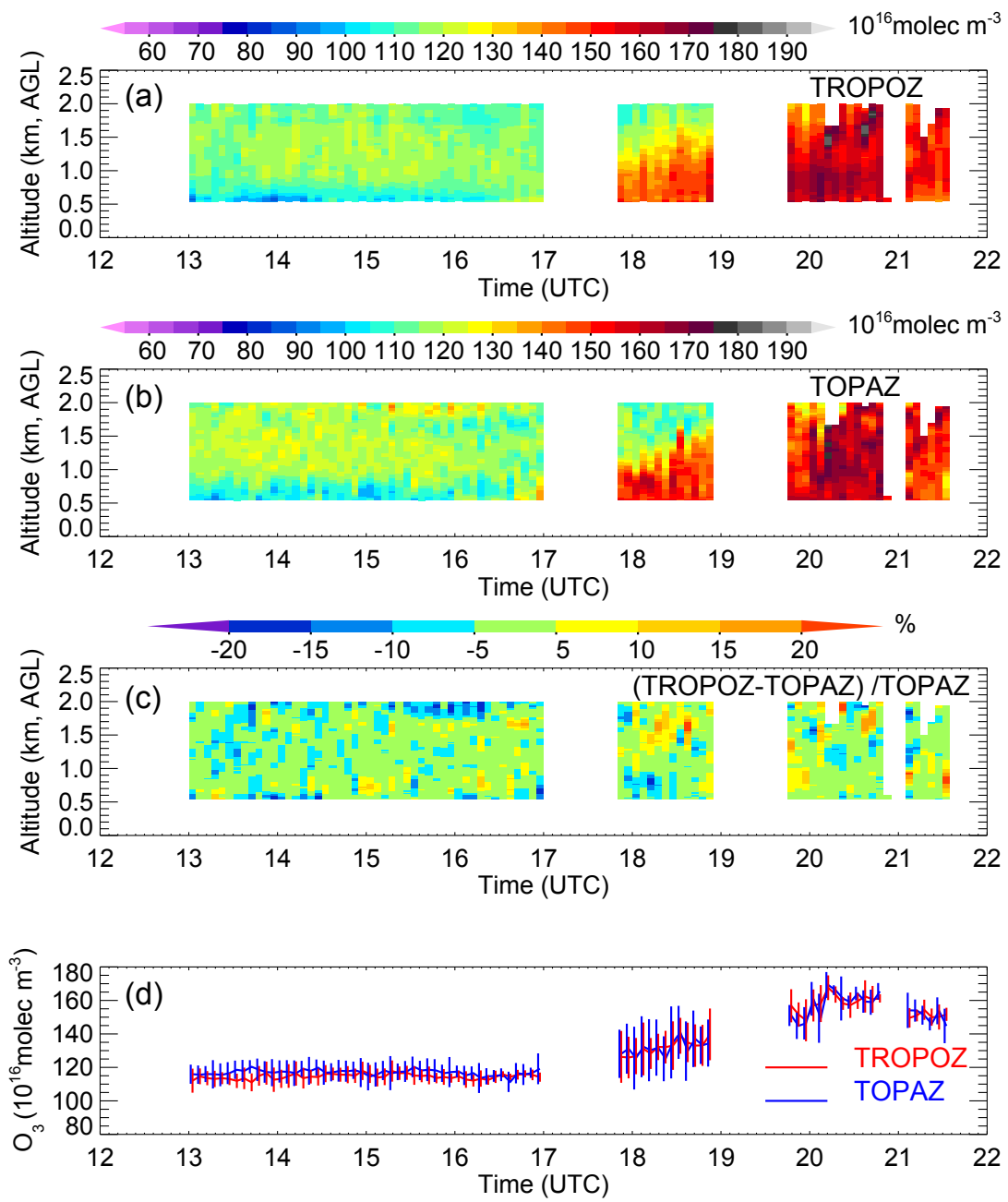

Figure 1. Comparisons of ozone measured by TROPOZ and TOPAZ. (a) Ozone number densities measured by TROPOZ. (b) Ozone number densities measured by TOPAZ. (c) Their relative percent differences, (TROPOZ-TOPAZ)/TOPAZ. (d) Column averages measured by the TROPOZ and TOPAZ as well as their $1 \sigma$ standard deviations. TROPOZ measures $1.1 \pm 2.6 \%$ lower ozone column average than TOPAZ.

Table 3. Comparisons of the ozone column average measured by TROPOZ, TOPAZ, and LMOL.

\begin{tabular}{lrrlrrrrr}
\hline Date & $\begin{array}{r}\text { UTC time } \\
\text { range }\end{array}$ & $\begin{array}{r}\text { Altitude } \\
\text { range } \\
(\mathrm{km})\end{array}$ & & $\begin{array}{r}\text { Lumber of } \\
\text { the paired } \\
\text { profiles }\end{array}$ & $\begin{array}{r}\text { Mean ozone } \\
\text { column average } \\
\left(10^{16} \mathrm{molec} \mathrm{m}^{-3}\right)\end{array}$ & $\begin{array}{r}1 \sigma \text { of the ozone } \\
\text { column average } \\
\left(10^{16} \mathrm{molec} \mathrm{m}^{-3}\right)\end{array}$ & $\begin{array}{r}\text { Mean } \\
\text { relative } \\
\text { difference* }\end{array}$ & $\begin{array}{r}1 \sigma \text { of the } \\
\text { difference }\end{array}$ \\
\hline 11 July 2014 & $13: 00-21: 35$ & $0.6-2$ & TROPOZ/TOPAZ & 80 & $127.3 / 128.6$ & $17.8 / 16.7$ & $-1.1 \%$ & $2.6 \%$ \\
16 July 2014 & $13: 35-17: 30$ & $0.9-2$ & LMOL/TOPAZ & 28 & $98.1 / 102.0$ & $13.1 / 13.0$ & $-3.8 \%$ & $2.9 \%$ \\
\hline
\end{tabular}

* Equal to mean $(\mathrm{A}-\mathrm{B}) / \mathrm{B}$ for $\mathrm{A} / \mathrm{B}$ in "lidar" column for all paired profiles.

sonde-measured pressure and temperature profiles and averaged over a $30 \mathrm{~min}$ interval $( \pm 15 \mathrm{~min}$ around sonde launch times). Ozonesondes and lidars do not sample exactly the same atmospheric volume because the sondes typically drift horizontally. Therefore, discrepancies between the lidar and sonde observations may be in part due to real atmospheric differences. The horizontal displacement of the sonde usually increases with altitude, so the distance between sonde and li- dar is normally larger in the free troposphere than in the PBL. However, horizontal ozone gradients tend to be smaller in the free troposphere than in the PBL, which typically keeps atmospheric differences rather small despite the increased displacement of the sonde. The ozonesondes report values approximately every second (about every $5 \mathrm{~m}$ in altitude) in raw data. For comparison, the ozonesonde raw data were linearly interpolated on the lidar altitude grids with a $15 \mathrm{~m}$ interval. 

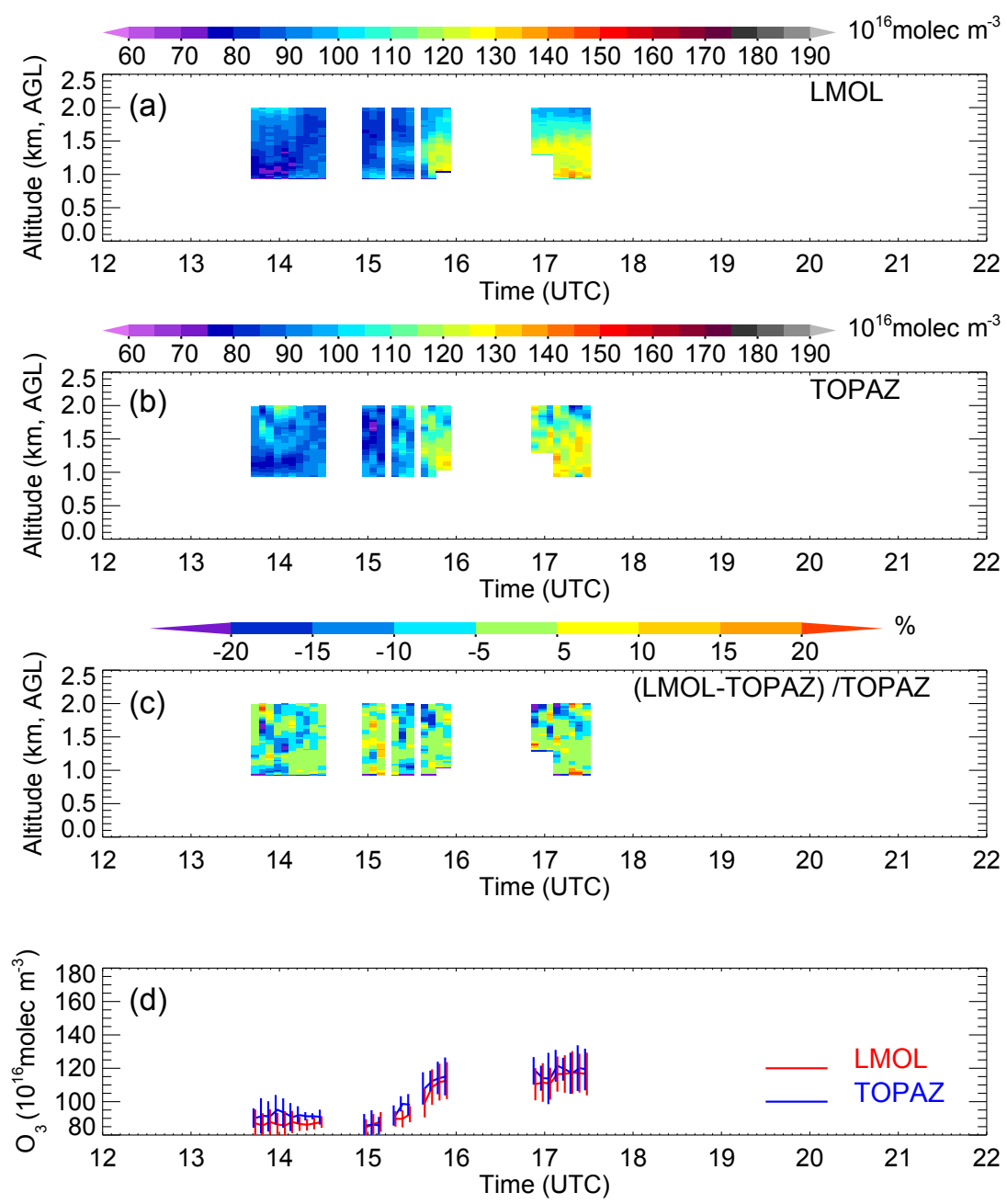

Figure 2. Comparisons of ozone measured by LMOL and TOPAZ. (a) LMOL-measured ozone number densities. (b) TOPAZ-measured ozone number densities. (c) Their relative percent differences, (LMOL-TOPAZ)/TOPAZ. (d) Column averages measured by LMOL and TOPAZ as well as their $1 \sigma$ standard deviations. LMOL measures $3.8 \pm 2.9 \%$ lower ozone column average than TOPAZ.

Figure 3 shows the mean ozone mixing ratios measured by TOLNet lidars and ozonesondes, as well as their mean relative difference as function of altitude.

After the DISCOVER-AQ/FRAPPÉ campaign started, the TROPOZ lidar deployed to Fort Collins, CO, to measure ozone. There were 11 ozonesonde profiles that were coincident and co-located with the TROPOZ measurements. The mean ozone profiles of TROPOZ and sondes (Fig. 3a) show similar vertical variations with enhanced $\mathrm{PBL}$ and upper tropospheric ozone. The mean relative differences between TROPOZ and ozonesondes (black line in Fig. 3b) are mostly within $\pm 10 \%$ up to $9 \mathrm{~km}$. The local maximum of the differences at $1.8 \mathrm{~km}$ is associated with the merging of ozone retrievals from the near-field channel and far-field channel. The green lines in Fig. 3b represent the expected total measurement uncertainties, including the lidar measurement uncertainties for a $30 \mathrm{~min}$ integration time (also see Table 2) and a $10 \%$ constant uncertainty (accuracy) for ozonesondes. The purple lines represent the $1 \sigma$ standard deviations of the mean differences, which can be compared to the combined precision of lidar (i.e., statistical uncertainty) and ozonesonde $(5 \%)$. The $1 \sigma$ standard deviation increases from about $10 \%$ in the lower troposphere to about $20 \%$ in the upper troposphere as a result of increasing lidar statistical uncertainties with altitude. Below $9 \mathrm{~km}$, the $1 \sigma$ standard deviations of the mean differences are mostly located within the range of the expected uncertainties. In particular, the lidar-sonde differences around $0.5 \mathrm{~km}$ are significantly less than the expected uncertainties suggesting that the detection and counting systems of TROPOZ performed better than anticipated. Above $9 \mathrm{~km}$, the biases increase and exceed $25 \%$ with large oscillations due to large statistical errors as a consequence of low SNR. However, ozone observations with biases between 10 and $20 \%$ are still representative of the upper free troposphere. On average, TROPOZ measures $2.9 \%$ higher ozone than the ozonesondes for altitudes from 0.35 to $12 \mathrm{~km}$. This 
difference can be seen as the mean difference of ozone column average between the ozonesondes and lidar for a $30 \mathrm{~min}$ integration time.

Between 10 and 16 July, a total of 10 ozonesondes were released near the BAO tower and 7 of them were coincident with TOPAZ measurements ( 3 on 10 July, 3 on 11 July, and 1 on 16 July). TOPAZ mostly agrees with ozonesondes between -5 and $10 \%$ (black line in Fig. 3d). The $1 \sigma$ standard deviation of the mean differences (purple lines) is about $5 \%$, which is close to the combined precision of TOPAZ and ozonesondes (about $6 \%$ ). $1 \sigma$ of the mean differences stays almost entirely within the expected uncertainties indicative of a proper estimate of the lidar measurement uncertainties for TOPAZ in Table 2. Compared to ozonesondes, TOPAZ measures $4.4 \%$ more PBL ozone on average.

On 16 July, there was only one pair of coincident LMOL and ozonesonde measurements at the BAO tower (Fig. 3e, f). The $30 \mathrm{~min}$ averaged LMOL ozone profile agrees with the ozonesonde mostly within $0-15 \%$ between 0.95 and $4.5 \mathrm{~km}$ a.g.l. with an overall average of $6.2 \%$. The maximum bias occurring at far range (above $4 \mathrm{~km}$ ) is principally due to low SNR. The bias observed at $1.5 \mathrm{~km}$ is likely due to the high variation in aerosol concentration and associated uncertainties in the aerosol correction. Since there is only one LMOL-ozonesonde comparison, the statistical information on the overall bias between their measurements is not available.

In summary, all three TOLNet lidars measured higher ozone than ozonesondes with mean ozone column differences of $2.9 \%$ for TROPOZ, $4.4 \%$ for TOPAZ, and $6.2 \%$ for LMOL (based on a single profile comparison). The differences between the two types of instruments and the standard deviations are mostly less than the expected uncertainties. The largest bias occurs at far-range altitudes as expected and is primarily associated with the high statistical errors arising from low SNR. The increased bias at near-range altitudes could be associated with various factors, primarily the aerosol correction and the merging of the signals or ozone retrievals from different optical or altitude channels.

\subsection{Lidars versus P-3B chemiluminescence instrument}

During the campaigns, the P-3B aircraft measured ozone profiles while doing spirals above the lidar sites. There are 34 coincident profiles between TROPOZ and the P-3B at Fort Collins, 29 between TOPAZ and the P-3B at the BAO tower, and 9 between LMOL and the P-3B at Golden, CO. The distances between the lidar and the $\mathrm{P}-3 \mathrm{~B}$ spiral centers for these paired profiles were less than $11 \mathrm{~km}$. To make coincident pairs between P-3B and lidar data, we interpolate the P-3B data onto the lidar vertical grids with a $15 \mathrm{~m}$ vertical resolution. Figure 4 shows the average ozone profiles measured by the lidars and the $\mathrm{P}-3 \mathrm{~B}$ as well as their mean relative differences. TROPOZ and the P-3B agree with each other within $\pm 5 \%$ between 0.5 and $3.5 \mathrm{~km}$ (black lines in Fig. $4 \mathrm{~b}$ ) with a
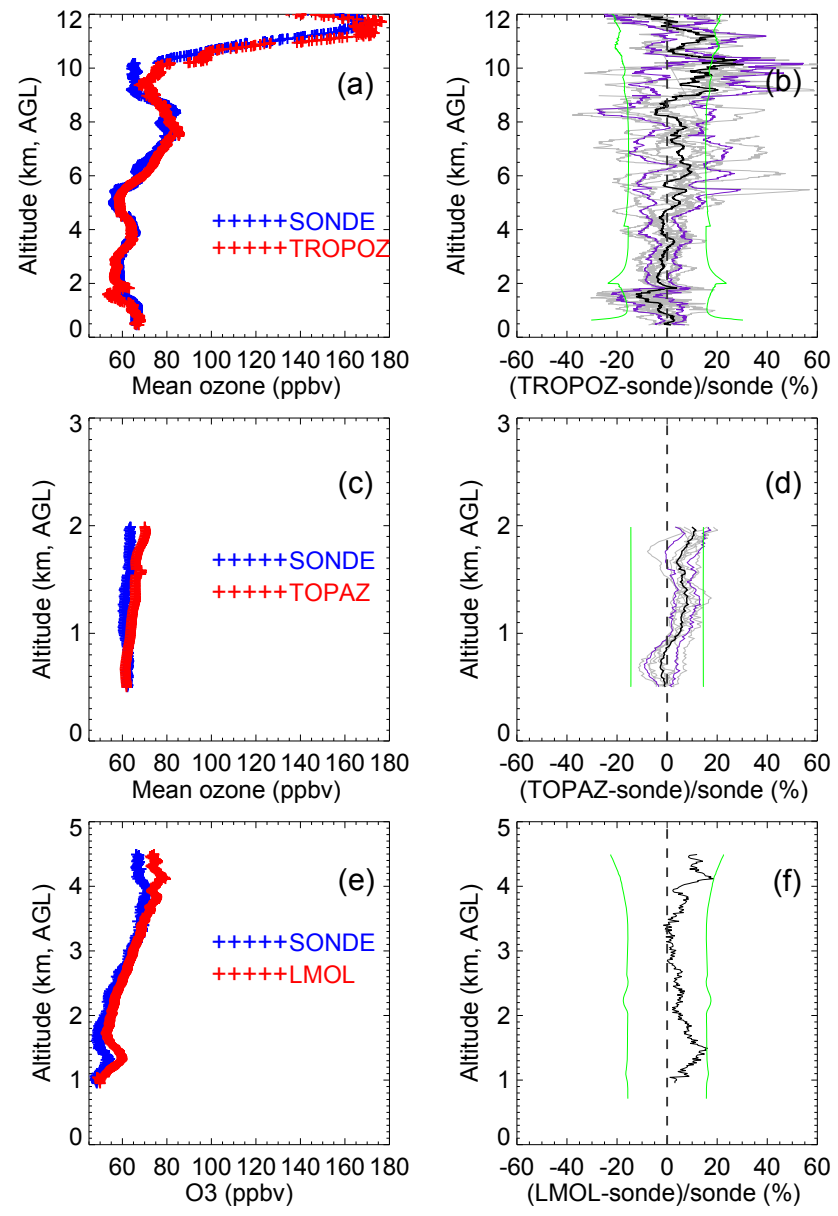

Figure 3. Comparisons of lidar and ozonesonde measurements. (a) Average ozone profiles measured by TROPOZ and ozonesondes at Fort Collins, CO (11 pairs). (b) Mean relative difference (black) between TROPOZ and ozonesondes as well as the $1 \sigma$ standard deviations (purple). (c) Average ozone profiles measured by TOPAZ and ozonesondes at BAO tower (7 pairs). (d) Mean relative difference (black) between TOPAZ and ozonesondes as well as the $1 \sigma$ standard deviations (purple). (e) Average ozone profiles measured by LMOL and ozonesonde at the BAO tower (1 pair). (f) Relative difference between LMOL and ozonesonde. The gray lines represent the individual difference profiles between the lidar and sondes. The green lines represent the expected uncertainties, including the 30 min lidar measurement uncertainties (also see Table 2) and a $10 \%$ constant uncertainty for ozonesondes.

$-0.8 \%$ overall average relative difference. The $1 \sigma$ standard deviation of the mean differences (purple lines in Fig. 4b) stays almost entirely within the expected uncertainties (green lines), which include both calculated lidar measurement uncertainties and a $5 \%$ constant uncertainty (accuracy) for the P-3B. TOPAZ agrees with the P-3B within -11 and $3 \%$ between 0.5 and $2 \mathrm{~km}$ (Fig. $4 \mathrm{c}$, d) with a $-2.7 \%$ overall average relative difference. TOPAZ underestimates the lowerPBL $(<1.5 \mathrm{~km})$ ozone compared to P-3B, but when compared to ozonesondes TOPAZ overestimates ozone at many 

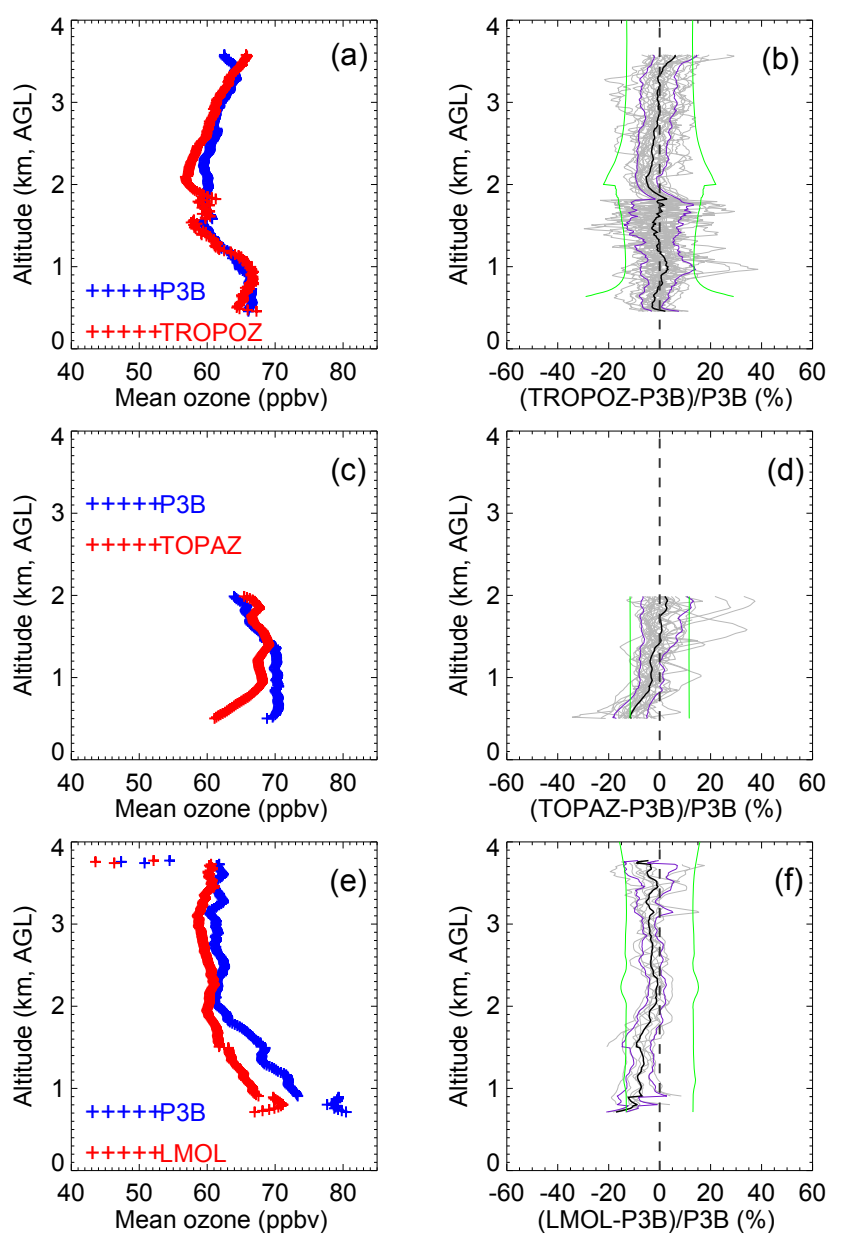

Figure 4. Intercomparison between the lidar and P-3B measurements. (a) Average ozone profiles measured by TROPOZ and P$3 \mathrm{~B}$ at Fort Collins, $\mathrm{CO}$ (34 profiles). (b) Mean relative difference (black) between TROPOZ and P-3B data as well as the $1 \sigma$ standard deviation (purple). (c) Average ozone profiles measured by TOPAZ and $\mathrm{P}-3 \mathrm{~B}$ at the BAO tower (29 profiles). (d) Mean relative difference between TOPAZ and P-3B data as well as the $1 \sigma$ standard deviation (purple). (e) Average ozone profiles measured by LMOL and P-3B at Golden, $\mathrm{CO}$ (9 profiles). (f) Mean relative difference between LMOL and P-3B data as well as the $1 \sigma$ standard deviation (purple). The gray lines represent the individual difference profiles between the lidar and sondes. The green lines represent the expected, uncertainties including the 30 min lidar measurement uncertainties (also see Table 2) and a $10 \%$ constant uncertainty for ozonesondes.

of these same altitudes (see Fig. 3d). LMOL agrees with P3B mostly within -5 and $0 \%$ above $1800 \mathrm{~m}$ and within -15 and $-5 \%$ between 0.7 and $1.8 \mathrm{~km}$ (Fig. $4 \mathrm{e}$, f) with a $-4.9 \%$ overall average relative difference. The $1 \sigma$ standard deviation of the LMOL-P3-B relative differences is mostly between 5 and $8 \%$ and is close to their combined precision $(6 \%)$. The $1 \sigma$ of the mean differences for both TOPAZ and LMOL (purple lines in Fig. 4d, f) stays within the expected uncertainty (green lines) except for the bottom altitudes.
In summary, TOPAZ and LMOL exhibited noticeable negative bias in the PBL compared to the P-3B while TROPOZ measured slightly lower than the P-3B. The differences between the three lidars and the $\mathrm{P}-3 \mathrm{~B}$ are not significantly correlated suggesting that these biases were not caused by the P-3B ozone instrument. These differences could at least in part be caused by the lidar systematic errors mentioned in Sect. 2.1.5 but could also reflect horizontal ozone variability across the P-3B spirals, which were up to $22 \mathrm{~km}$ in diameter.

\section{Summary and conclusions}

Intercomparisons have been made between three of the six TOLNet ozone lidars (NASA GSFC's TROPOZ, NOAA ESRL's TOPAZ, and NASA LaRC's LMOL) and between these lidars and other in situ ozone measurement instruments using coincident data during the 2014 DISCOVER-AQ and FRAPPÉ campaigns at NOAA's BAO in Erie, CO. On average, TROPOZ, TOPAZ, and LMOL reported very similar ozone amounts within their reported uncertainties for a $5 \mathrm{~min}$ signal integration time. The three lidars measured consistent ozone variations revealed in the lidar time-height curtains and in the distribution of their relative differences. From intercomparisons between the lidars and other instruments we find the following:

1. All of the lidars measure higher ozone than ozonesondes with an average relative difference within $4.4 \%$. The lidar profile measurements agree with the ozonesonde observations within $-10-15 \%$ except at a few far-field altitudes. These results are generally consistent with Sullivan et al. (2015) from a similar ozonesonde-lidar intercomparison.

2. TROPOZ agrees with the P-3B chemiluminescence instrument below $3.5 \mathrm{~km}$ within $\pm 5 \%$ with a small column-averaged relative difference of $-0.8 \%$. TOPAZ and LMOL exhibit a slightly larger bias mostly between -15 and $5 \%$ below $2 \mathrm{~km}$ compared to the P-3B with a column-averaged difference of -2.7 and $-4.9 \%$, respectively.

Comparisons between the three TOLNet lidars and with in situ instruments suggest that the lidars are capable of capturing high temporal tropospheric ozone variability and of measuring tropospheric ozone with an accuracy better than $\pm 15 \%$ in terms of their vertical resolving capability and better than $\pm 5 \%$ in terms of their column measurement. These lidars have sufficient accuracy for model evaluation and satellite validation (Liu et al., 2010). Since the 2014 campaigns, all of the TOLNet lidars have been modified to improve their stability and their accuracy. The validation of these upgraded lidars will be reported in a future paper. 
Data availability. The ozone lidar data are available at the TOLNet website, https://www-air.larc.nasa.gov/missions/TOLNet/. The ozonesonde and P-3B data used in this study can be obtained at the DISCOVER-AQ website, https://www-air.larc.nasa.gov/ cgi-bin/ArcView/discover-aq.co-2014.

Competing interests. The authors declare that they have no conflict of interest.

Acknowledgements. This work is supported by the TOLNet program developed by the National Aeronautics and Space Administration (NASA)'s Science Mission Directorate and by the National Oceanic and Atmospheric Administration Earth System Research Laboratory. The authors would like to thank the DISCOVER-AQ team, especially James H. Crawford who organized and coordinated the simultaneous ground-based, sounding and airborne measurements. John T. Sullivan's research was supported by an appointment to the NASA Postdoctoral Program at the NASA Goddard Space Flight Center, administered by Universities Space Research Association under contract with NASA. The views, opinions, and findings contained in this report are those of the authors and should not be construed as an official NOAA, NASA, or US government position, policy, or decision.

Edited by: Andreas Hofzumahaus

Reviewed by: two anonymous referees

\section{References}

Alvarez, R. J., Senff, C. J., Langford, A. O., Weickmann, A. M., Law, D. C., Machol, J. L., Merritt, D. A., Marchbanks, R. D., Sandberg, S. P., Brewer, W. A., Hardesty, R. M., and Banta, R. M.: Development and Application of a Compact, Tunable, Solid-State Airborne Ozone Lidar System for Boundary Layer Profiling, J. Atmos. Ocean. Tech., 28, 1258-1272, https://doi.org/10.1175/JTECH-D-10-05044.1, 2011.

Bowman, K. W.: Toward the next generation of air quality monitoring: Ozone, Atmos. Environ., 80, 571-583, 2013.

Brion, J., Chakir, A., Daumont, D., and Malicet, J.: High-resolution laboratory absorption cross section of $\mathrm{O}_{3}$ temperature effect, Chem. Phys. Lett., 213, 510-512, 1993.

Browell, E. V., Ismail, S., and Shipley, S. T.: Ultraviolet DIAL measurements of $\mathrm{O}_{3}$ profiles in regions of spatially inhomogeneous aerosols, Appl. Optics, 24, 2827-2836, 1985.

Crawford, J. H. and Pickering, K. E.: DISCOVER-AQ: Advancing strategies for air quality observations in the next decade, Environ. Manage., September, 4-7, 2014.

Daumont, D., Brion, J., Charbonnier, J., and Malicet, J.: Ozone UV spectroscopy I: Absorption cross-sections at room temperature, J. Atmos. Chem., 15, 145-155, 1992.

Deshler, T., Mercer, J. L., Smit, H. G. J., Stubi, R., Levrat, G., Johnson, B. J., Oltmans, S. J., Kivi, R., Thompson, A. M., Witte, J., Davies, J., Schmidlin, F. J., Brothers, G., and Sasaki, T.: Atmospheric comparison of electrochemical cell ozonesondes from different manufacturers, and with different cathode solution strengths: The balloon experiment on standards for ozonesondes, J. Geophys. Res., 113, D04307, https://doi.org/10.1029/2007JD008975, 2008.

De Young, R., Carrion, W., Ganoe, R., Pliutau, D., Gronoff, G., Berkoff, T., and Kuang, S.: Langley mobile ozone lidar: ozone and aerosol atmospheric profiling for air quality research, Appl. Optics, 56, 721-730, https://doi.org/10.1364/ao.56.000721, 2017.

Dingle, J. H., Vu, K., Bahreini, R., Apel, E. C., Campos, T. L., Flocke, F., Fried, A., Herndon, S., Hills, A. J., Hornbrook, R. S., Huey, G., Kaser, L., Montzka, D. D., Nowak, J. B., Reeves, M., Richter, D., Roscioli, J. R., Shertz, S., Stell, M., Tanner, D., Tyndall, G., Walega, J., Weibring, P., and Weinheimer, A.: Aerosol optical extinction during the Front Range Air Pollution and Photochemistry Éxperiment (FRAPPÉ) 2014 summertime field campaign, Colorado, USA, Atmos. Chem. Phys., 16, 11207-11217, https://doi.org/10.5194/acp-16-11207-2016, 2016.

Donovan, D. P., Whiteway, J. A., and Carswell, A. I.: Correction for nonlinear photon-counting effects in lidar systems, Appl. Optics, 32, 6742-6753, 1993.

Eisele, H. and Trickl, T.: Improvements of aerosol algorithm in ozone lidar data processing by use of evolutionary strategies, Appl. Optics, 44, 2638-2651, 2005.

Flentje, H., Claude, H., Elste, T., Gilge, S., Köhler, U., PlassDülmer, C., Steinbrecht, W., Thomas, W., Werner, A., and Fricke, W.: The Eyjafjallajökull eruption in April 2010 - detection of volcanic plume using in-situ measurements, ozone sondes and lidar-ceilometer profiles, Atmos. Chem. Phys., 10, 10085-10092, https://doi.org/10.5194/acp-10-10085-2010, 2010.

Godin, S. M., Carswell, A. I., Donovan, D. P., Claude, H., Steinbrecht, W., McDermid, I. S., McGee, T. J., Gross, M. R., Nakane, H., Swart, D. P. J., Bergwerff, H. B., Uchino, O., von der Gathen, P., and Neuber, R.: Ozone differential absorption lidar algorithm intercomparison, Appl. Optics, 38, 6225-6236, 1999.

Heikes, B. G., Kok, G. L., Walega, J. G., and Lazrus, A. L.: $\mathrm{H}_{2} \mathrm{O}_{2}$, $\mathrm{O}_{3}$ and $\mathrm{SO}_{2}$ measurements in the lower troposphere over the eastern United States during fall, J. Geophys. Res., 92, 915-931, 1987.

Immler, F.: A new algorithm for simultaneous ozone and aerosol retrieval from tropospheric DIAL measurements, Appl. Phys. BLasers O., 76, 593-596, 2003.

Johnson, B. J., Helmig, D., and Oltmans, S.: Evaluation of ozone measurements from a tethered balloon-sampling platform at South Pole Station in December 2003, Atmos. Environ., 42, 2780-2878, https://doi.org/10.1016/j.atmosenv.2007.03.043, 2008.

Komhyr, W. D.: Electrochemical cells for gas analysis, Ann. Geophys., 25, 203-210, 1969.

Komhyr, W. D., Barnes, R. A., Brothers, G. B., Lanthrop, J. A., and Opperman, D. P.: Electrochemical concentration cell ozonesonde performance evaluation during STOIC 1989, J. Geophys. Res., 100, 9231-9244, 1995.

Kovalev, V. A. and Bristow, M. P.: Compensational threewavelength differential-absorption lidar technique for reducing the influence of differential scattering on ozone-concentration measurements, Appl. Optics, 35, 4790-4797, 1996.

Kuang, S., Burris, J. F., Newchurch, M. J., Johnson, S., and Long, S.: Differential Absorption Lidar to Measure Subhourly Variation of Tropospheric Ozone Profiles, IEEE T. Geosci. Remote, 
49, 557-571, https://doi.org/10.1109/TGRS.2010.2054834, 2011.

Kuang, S., Newchurch, M. J., Burris, J., and Liu, X.: Ground-based lidar for atmospheric boundary layer ozone measurements, Appl. Optics, 52, 3557-3566, https://doi.org/10.1364/AO.52.003557, 2013.

Langford, A. O., Senff, C. J., Alvarez II, R. J., banta, R. M., Hardesty, M., Parrish, D. D., and Ryerson, T. B.: Comparison between the TOPAZ airborne ozone lidar and in situ measurements during TexAQS 2006, J. Atmos. Ocean. Technol., 28, 1243-1257, https://doi.org/10.1175/JTECH-D-10-05043.1 2011.

Langford, A. O., Alvarez, R. J., Brioude, J., Fine, R., Gustin, M., Lin, M. Y., Marchbanks, R. D., Pierce, R. B., Sandberg, S. P., Senff, C. J., Weickmann, A. M., and Williams, E. J.: Entrainment of stratospheric air and Asian pollution by the convective boundary layer in the Southwestern U.S., J. Geophys. Res.-Atmos., 122, 1312-1337, https://doi.org/10.1002/2016JD025987, 2016.

Leblanc, T., Sica, R. J., van Gijsel, J. A. E., Godin-Beekmann, S., Haefele, A., Trickl, T., Payen, G., and Gabarrot, F.: Proposed standardized definitions for vertical resolution and uncertainty in the NDACC lidar ozone and temperature algorithms Part 1: Vertical resolution, Atmos. Meas. Tech., 9, 4029-4049, https://doi.org/10.5194/amt-9-4029-2016, 2016 a.

Leblanc, T., Sica, R. J., van Gijsel, J. A. E., Godin-Beekmann, S., Haefele, A., Trickl, T., Payen, G., and Liberti, G.: Proposed standardized definitions for vertical resolution and uncertainty in the NDACC lidar ozone and temperature algorithms - Part 2: Ozone DIAL uncertainty budget, Atmos. Meas. Tech., 9, 4051-4078, https://doi.org/10.5194/amt-9-4051-2016, 2016b.

Liu, G., Tarasick, D. W., Fioletov, V. E., Sioris, C. E., and Rochon, Y. J.: Ozone correlation lengths and measurement uncertainties from analysis of historical ozonesonde data in North America and Europe, J. Geophys. Res., 114, D04112, https://doi.org/10.1029/2008JD010576, 2009.

Liu, X., Bhartia, P. K., Chance, K., Spurr, R. J. D., and Kurosu, T. P.: Ozone profile retrievals from the Ozone Monitoring Instrument, Atmos. Chem. Phys., 10, 2521-2537, https://doi.org/10.5194/acp-10-2521-2010, 2010.

Malicet, C., Daumont, D., Charbonnier, J., Parisse, C., Chakir, A., and Brion, J.: Ozone UV spectroscopy. II. Absorption crosssections and temperature dependence, J. Atmos. Chem., 21, $263-$ 273, 1995

McDermid, I. S., Godin, S. M., Lindqvist, L. O., Walsh, T. D., Burris, J., Butler, J., Ferrare, R., Whiteman, D., and McGee, T. J.: Measurement intercomparison of the JPL and GSFC stratospheric ozone lidar systems, Appl. Optics, 29, 4671-4676, 1990.

Newchurch, M. J., Kuang, S., Leblanc, T., Alvarez, R. J., Langford, A. O., Senff, C. J., Burris, J. F., McGee, T. J., Sullivan, J. T., DeYoung, R. J., and Al-Saadi, J.: TOLNET - A Tropospheric Ozone Lidar Profiling Network for Satellite Continuity and Process Studies, EPJ Web of Conferences, 119, 20001, https://doi.org/10.1051/epjconf/201611920001, 2016.
Papayannis, A., Ancellet, G., Pelon, J., and Mégie, G.: Multiwavelength lidar for ozone measurements in the troposphere and the lower stratosphere, Appl. Optics, 29, 467-476, 1990.

Ridley, B. A., Grahek, F. E., and Walega, J. G.: A small highsensitivity, medium-response ozone detector suitable for measurements from light aircraft, J. Atmos. Ocean. Tech., 9, 142148, 1992.

Rufus, J., Stark, G., Smith, P. L., Pickering, J. C., and Thorne, A. P.: High-resolution photoabsorption cross section measurements of $\mathrm{SO}_{2}, 2: 220$ to $325 \mathrm{~nm}$ at $295 \mathrm{~K}$, J. Geophy. Res., 108, 5011, https://doi.org/10.1029/2002JE001931, 2003

Schenkel, A. and Broder, B.: Interference of some trace gases with ozone measurements by the KI method, Atmos. Environ., 16, 2187-2190, 1982.

Senff, C. J., Alvarez, R. J., Hardesty, R. M., Banta, R. M., and Langford, A. O.: Airborne lidar measurements of ozone flux downwind of Houston and Dallas, J. Geophys. Res., 115, D20307, https://doi.org/10.1029/2009JD013689, 2010.

Smit, H. G. J., Straeter, W., Johnson, B. J., Oltmans, S. J., Davies, J., Tarasick, D. W., Hoegger, B., Stubi, R., Schmidlin, F. J., Northam, T., Thompson, A. M., Witte, J. C., Boyd, I., and Posny, F.: Assessment of the performance of ECC-ozonesondes under quasi-flight conditions in the environmental simulation chamber: Insights from the Juelich Ozone Sonde Intercomparison Experiment (JOSIE), J. Geophys. Res., 112, D19306, https://doi.org/10.1029/2006JD007308, 2007.

Stauffer, R. M., Morris, G. A., Thompson, A. M., Joseph, E., Coetzee, G. J. R., and Nalli, N. R.: Propagation of radiosonde pressure sensor errors to ozonesonde measurements, Atmos. Meas. Tech., 7, 65-79, https://doi.org/10.5194/amt-7-65-2014, 2014.

Steinbrecht, W., McGee, T. J., Twigg, L. W., Claude, H., Schönenborn, F., Sumnicht, G. K., and Silbert, D.: Intercomparison of stratospheric ozone and temperature profiles during the October 2005 Hohenpeißenberg Ozone Profiling Experiment (HOPE), Atmos. Meas. Tech., 2, 125-145, https://doi.org/10.5194/amt-2125-2009, 2009.

Sullivan, J. T., McGee, T. J., Sumnicht, G. K., Twigg, L. W., and Hoff, R. M.: A mobile differential absorption lidar to measure sub-hourly fluctuation of tropospheric ozone profiles in the Baltimore-Washington, D.C. region, Atmos. Meas. Tech., 7, 3529-3548, https://doi.org/10.5194/amt-7-3529-2014, 2014.

Sullivan, J. T., McGee, T. J., DeYoung, R., Twigg, L. W., Sumnicht, G. K., Pliutau, D., Knepp, T., and Carrion, W.: Results from the NASA GSFC and LaRC Ozone Lidar Intercomparison: New Mobile Tools for Atmospheric Research, J. Atmos. Ocean. Tech., 32, 1779-1795, https://doi.org/10.1175/JTECHD-14-00193.1, 2015.

Weinheimer, A. J., Walega, J. G., Ridley, B. A., Sache, G. W., Anderson, B. E., and Collins Jr., J. E.: Stratospheric $\mathrm{NO}_{\mathrm{y}}$ measurements on the NASA DC-8 during AASE II, Geophys. Res. Lett., 20, 2563-2566, 1993. 